\title{
AN INSIGHT INTO THE VALUE ADDED TAX SYSTEM DETAILING ITS ORIGINS, IMPACT, PROVISIONS AND REGULA- TIONS WITH REFERENCE TO INDIA
}

\author{
Tomy Kallarackal*
}

\section{International History of VAT}

The Value Added Tax was first introduced in France in 1954. It was the resultant effort of France and members of the European Economic Community (E.E.C) during the 1950s aimed at the simplification of commodity taxes. Currently more than 130 nations in the world have adopted the VAT system. In the last decade alone over 50 nations have introduced VAT. This includes implementation in China and most recently the addition of Australia to the list of VAT nations. The world over, VAT is payable on both goods and services as they constitute a part of the national GDP. Excise duty and sales taxes are merged into the singularity of VAT. No tax is levied on exports with full input tax credit made available.

The scheme of taxation adopted by most nations is very simple. The seller of goods and the service provider charge tax on sales, avail input tax credit and pay the difference as VAT to the government treasury. The compliance system in VAT nations is also very simple. There is very less interface between the tax collector and the tax payer. However there are provisions for heavy penalization of VAT defaulters. VAT is administered nationally and is also levied on imports.

* SGL, Dept. of Commerce, Christ College, Bangalore. 


\section{Characteristics of Sales Tax in India Today}

Sales tax is levied at the central and state level depending upon the nature of sale. The rate of taxation on the sale of goods ranges from 0 to $20 \%$. Sales tax is levied only on first sale and at the first stage. Surcharge, additional tax, TOT and entry tax on entry of specified goods are levied by certain states only. Certain municipalities and corporations charge octroi. Exports and imports are not liable for sales tax. The tax system and rates vary from state to state.

\section{VAT in India}

In India the reforms process started in 1991. The National Institute of Public Finance and Policy (NIPEP) studied the indirect taxation system in India and recommended the independent dual VAT system to replace state sales tax and central sales tax. In May 1994, the Empowered Committee (E.C.) of all Finance Ministers of the states was constituted with the task of successfully launching the state and central VAT system in India.

The EC has decided to implement the VAT system in India in a phased manner:

*PHASE-1 - Abolition of Sales Tax Incentive Schemes from 1.1.2000.

*PHASE-2 - To sort out issues pending with the Central and State Govts. Before the implementation of the State VAT System from 1.4.2003 in all states and UTS.

* PHASE-3 - To implement the Interstate (Central) VAT System to replace Central Sales Tax (C.S.T.) all over India.

\section{Current Status of VAT in India:}

It was expected that all the states and UTs will implement the State VAT system from 1.4.2003. More than 24 states have released the "State Draft VAT Acts" and are in the process of tabling 'State VAT Bills' in their respective State Assemblies. All the states have drafted their respective VAT bills on the basis of 'Model VAT Bill 2003' prepared by Dr. B.R. Atre. The Central Govt. would provide 100\% compensation towards the loss in revenue during the first year of VAT to all states. 


\section{What is VAT? How does the System Work?}

It is a multipoint tax system with set off available for tax paid on corresponding purchases. Local sales tax will be substituted by VAT, a state Act and not a central Act. The full tax is collected at each transaction but paid on the Value Added Portions only and therefore is called Value Added Tax or VAT. The tax is levied on the final consumption and hence the final burden of the sales tax is borne by the local consumer. As an exception no VAT is charged on goods exported. The cumulative input tax burden would be refunded to the exporter. Tax paid on purchases is no longer a cost. A self assessment scheme will be available under VAT wherein assessments are likely to be carried out on the premises of the dealer.

\section{Differences between Sales Tax and VAT}

Current Tax

Single point

Multiple Rates

Concessional rates of tax

Purchase for export exempt

Subject to conditions.

Inter State sale taxable

All dealers do not pay tax. Only the manufacture and either the first or last seller pays tax.

\section{Value Added Tax}

Multiple point

Only $0,1,4,12.5$ and higher rates

No concessional rate of tax

Purchase for export will not be exempt. Tax paid on purchase for export will be refunded.

Inter state sale taxable but will be progressively reduced to $0 \%$ by 2006 .

Every Registered Dealer will pay tax.

\section{Design of the State VAT System}

No local Declaration Forms which allow concessional or tax free purchase will be made available whatsoever. Only a few taxes on commodities will be levied and all essential commodities will be fully exempted from taxation. Basic raw materials and industrial inputs will be taxed @ 4\%, gold and silver articles will be taxed @ 1\% and liquor@20\%. The R.N.R. (Revenue Neutral Rate) will be set@12.5. 
VAT will be calculated using the formula: $\quad \mathrm{VAT}=0 . \mathrm{-1}$;

$$
\text { Where } \begin{aligned}
O & =\text { Output Tax } \\
I & =\text { Input Tax }
\end{aligned}
$$

Retention by the State Government will be @ 4\% on local inputs when the corresponding goods are transferred to branches / depots outside the state. (A partial rebate of input tax credit is provided to such manufacturers.) Non VA Table entry tax is prohibited under the VAT regime. CST will continue. However the rate of taxation will be reduced to $2 \%$ in 2003-04, $1 \%$ in 2004-05 and 0\% in 2005-06. No Exemption Schemes are available. Any Exemption Scheme will be converted to a Deferral Scheme for the existing schemes.

While finalizing the incentive scheme under the VAT regime the state would have to consider the following:

1) The interests of incentive units must be protected.

2) The VAT design should not be disturbed.

\section{VAT - Key Terminologies:}

- Input Tax : Input tax is paid by the registered dealer on purchases within the state.

- Input Tax Credit: Tax paid to a registered dealer for purchase within the state.

- The Qualifying Purchases are-

- Goods purchased for use in manufacturing.

- Goods bought for resale.

- Packing materials.

- Capital goods used in the process of manufacturing.

- Items not qualifying for input tax credit

- Inter state purchases.

- Automobiles, air conditioners and their spare parts, unless he is a dealer.

- Food, beverages and tobacco products.

- Petroleum products, if not used in the production of goods or for industrial use. 
- Goods used for personal consumption and facilities to employees.

- Items used for the manufacture of exempted goods.

- Goods used as fuel in generation of energy.

- Gifts and samples.

- Input Tax Credit on Capital Goods-

- The definition of capital goods varies to a large extent from state to state. Many states do not allow input tax credit for the capital goods used by a trader. All capital goods purchases must be intimated to the concerned department in prescribed form. Input credit will be allowed for between 3 to 5 years.

- Restrictions on Input Tax Credit on Stock transfers

- On stock transferred outside the state, the dealer has to forgo $4 \%$ of input tax.

- Reversal of Input Tax Credit-

- On the sole condition that tax paid goods are lost or destroyed.

- Proof for Input Tax Credit

- The Original invoices from a registered dealer.

- Set off / Refund of Input Tax

- For the exporter, input tax credit will be refunded. For others, the excess of input tax over output tax can be šetoff against CST and any further excess can be carried forward to the next year.

- Output Tax

- Output Tax is payable by a registered dealer on the sale of goods within the state.

- Net Tax Payable

- It is calculated using the formula:

Output tax + Purchases tax (if any) - Eligible input tax credit. 


\section{Values on Which VAT is Chargeable}

VAT needs to be computed on the following if they have been charged separately:

- Basic Price

- Excise Duty

- Transport Cost/ Freight

- Clearing and Forwarding Charges

- Insurance

- Taxes and Duties levied under any law

- Cost of packing

\section{VAT Implementation and Business Issues}

The implementation of VAT is bound to affect business and commercial establishments in different proportions. The following data gives an insight as to the field specific impact of VAT after its implementation:

Sourcing - Interstate procurement would prove costlier than local procurements.

Distribution Structuring - Multisage taxation may need restructuring of current models.

Warehousing - Regional warehousing concept may undergo changes.

Stock transfers - Strategy needs to be reworked based on input credits and entry tax.

Costing - Certain taxes may not be VATable and thus may require cost benefit analysis.

Pricing - There is a need to ascertain the impact on final prices including MRP.

Inventory control - Cash flow impact must be determined.

Accounting and invoicing - There is an increased stress on documentation and record keeping. 
IT and related systems - Current IT packages do not factor VAT principles. Hence they may need to be made compliant.

Monitoring and litigation support - Settled points under sales lax may have limited use in the new regime

\section{Impact of VAT - (data models)}

\begin{tabular}{l|c|c}
\hline & Stock transfer & Within the State \\
\hline Material Cost & 100.00 & 100.00 \\
Tax on Inputs & 12.00 & 12.00 \\
Tax Rate & $12 \%$ & $12 \%$ \\
Value Addition & 50.00 & 50.00 \\
Setoff Available & 0.00 & 12.00 \\
\hline Total & 162.00 & 150.00 \\
VAT & 19.44 & 18.00 \\
Tax Rate & $12 \%$ & $12 \%$ \\
Net Price to Final Consumer & 181.44 & 168.00 \\
\hline
\end{tabular}

Result : As a Seller, Your Effective SP may be increased.

\section{Interstate V/S Local:}

\begin{tabular}{l|c|c}
\hline & Local & Interstate \\
\hline Material Cost & 100.00 & 100.00 \\
Input Tax * & 12.00 & 12.00 \\
Value Addition & 50.00 & 50.00 \\
Set off available to Vendor & $(12.00)$ & $(12.00)$ \\
Total & 150.00 & 150.00 \\
Sales Tax ${ }^{* *}$ & 18.00 & 6.00 \\
Set off available to Manufacturer & $(18.00)$ & $(0.0)$ \\
Net Input Cost to Manufacturer & 150.00 & 156.00 \\
\hline
\end{tabular}

* Sales Tax at $12 \%$

** Sales Tax at $12 \%$ and CST at $4 \%$

Result: Your purchases could become more expensive 


\section{VAT Compliance : Legal Requirements and Records Maintenance}

\section{Compliance Requirements:}

1. Registration

2. Returns - Payments

3. C.A. Audit

4. Departmental Audit

5. Survey - Information to the Sales Tax Dept.

Documentation (VAT):

1. VAT (Tax) Invoice

2. Purchase Register (Set off)

3. Sales Register

4. VAT Registration Certificate (Tin No.)

\section{Registration Procedures}

An application for VAT registration must be duly filled and submitted. Then a Certificate of Registration and Tax Identification Number must be obtained and displayed in the place of business at a conspicuous place. Any changes in the name, address, principal place of business, branches, classes of goods, etc. must be notified to the concerned authorities.

\section{Purchase Records}

These documents should be divided into five separate categories:

1. Details of purchases from suppliers who are not registered for VAT where no VAT is charged.

2. Details of purchases of goods exempt from VAT. 
3. Details of purchases of goods used for consumption for which input tax credit cannot be claimed (including details of goods used for personal consumption or given as gifts.)

4. Details of imports and purchases from other states.

5. Value and VAT paid on goods purchased at:

- $4 \%$ Rate of VAT

- Standard rate of VAT

- $1 \%$ Rate of VAT

- Where Special Additional Tax is charged

All purchase documents must be retained in chronological order. The original Tax invoices from VAT dealers and Purchase Invoices from non-VAT dealers and where input tax credit cannot be claimed must be filed separately.

\section{Sales Records}

All documents under this category must be divided into SEVEN separate segments

1. Value of exempt sales, stock transfers and consignment sales to other states.

2. Value of Zero rated sales (exports)

3. Value of Inter State Sales.

4. Value of taxable sales and VAT @ 4\%

5. Value of taxable sales and VAT @ 12.5\%

6. Value of taxable sales and VAT @ 1\%

7. Value of Special Additional Tax goods and SAT charged.

\section{Documents related to Exports}

The following are the documents to be maintained in the case of exports:

- A copy of the Customers Clearance Certificate.

- Evidence of transportation i.e. copies of transit documents, such as airway bills / shipping bills / road or rail transit. 
- $P O^{\prime}$ from or contracts with foreign customers.

- Copies of invoices issued to foreign customers.

- Evidence of payment of goods such as copy of letter of credit.

- Form H declaration.

- Copies of tax invoices related to taxable sales filed separately in date / serial order.

\section{Other Records to be maintained}

- Copies of credit and debit notes issued and received separately to be filed in chronological order under different tax rates.

- All cash records including cash books, all vouchers including petty cash vouchers, all account books and records of daily receipts including cash register rolls.

- Stock and manufacturing records to be retained.

- Orders and delivery notes.

- Job books.

- Annual accounts including Trading $a / c^{\prime} s, P \& L a / c^{\prime} s$ and $B / S$.

- Bank statements and pay in slips.

- All records must be retained for a specific period. Failure to maintain specified records will be penalised.

\section{Filing Returns}

Monthly and yearly returns must be filed in the specified formats. Apart from the monthly returns, additional returns may be required to be filed under orders of the Commissioner or any other authorized person. The time limit for filing returns can be extended on a written application to the concerned authority. Returns must be accompanied by proof of payment of tax. Tax must be paid within the due dates specified. 


\section{Audits}

The accuracy of self assessment will be checked through a system of departmental audit wherein a certain percentage of dealers will be taken up for audit every year on a scientific basis. More complying dealers will be audited less frequently. All dealers are expected to be audited once in 5 years and if evasion is detected during audit, the dealer may be assessed for all previous periods upto 5 years. The audit wing will be segregated from the tax collection and monitoring wing.

\section{Conclusion}

At present the VAT system has not been accepted by most states and its implementation has been delayed due to objections raised by the traders. Negotiations are underway between the traders and the Govt. of India wherein the focus is to allay the unfounded fears of traders attributed to the introduction of an entirely new system of taxation. It is only a matter of time that the VAT system will be implemented as its benefits in the long run are obvious and the usual resistance to change is but a minor hiccup. 